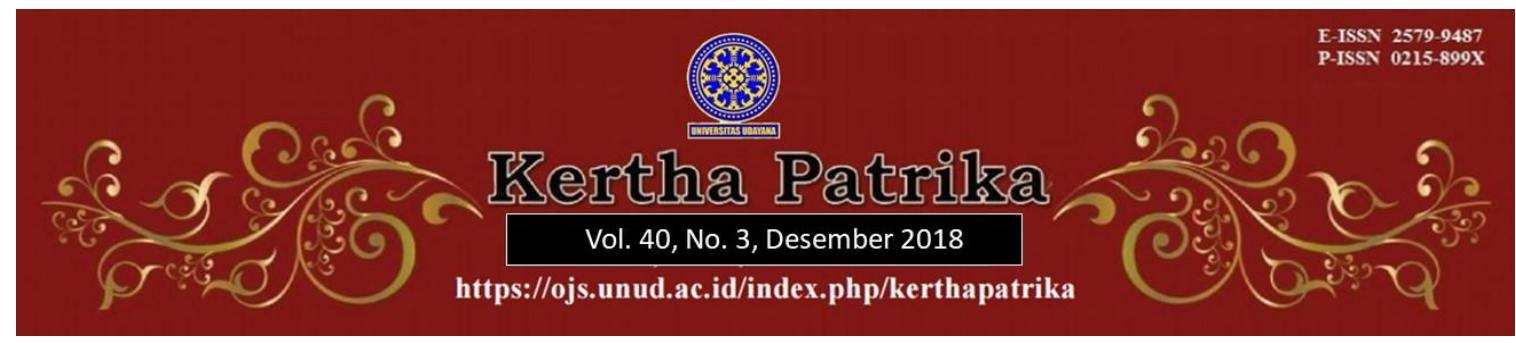

\title{
Efektifitas Pengawasan Komisi Yudisial Dalam Mengawasi Kode Etik Profesi Hakim
}

\author{
Nur Kautsar Hasan, ${ }^{1}$ Nasrun Hipan², Hardianto Djanggih ${ }^{3}$ \\ ${ }^{1}$ Pengadilan Negeri Bone, Sulawesi Selatan \\ 2 Fakultas Hukum Universitas Muhammadiyah Luwuk Banggai, \\ E-mail : nasrun.hipan@yahoo.com \\ ${ }^{3}$ Fakultas Hukum Universitas Tompotika Luwuk Banggai, \\ E-mail : hardianto.djanggih@gmail.com
}

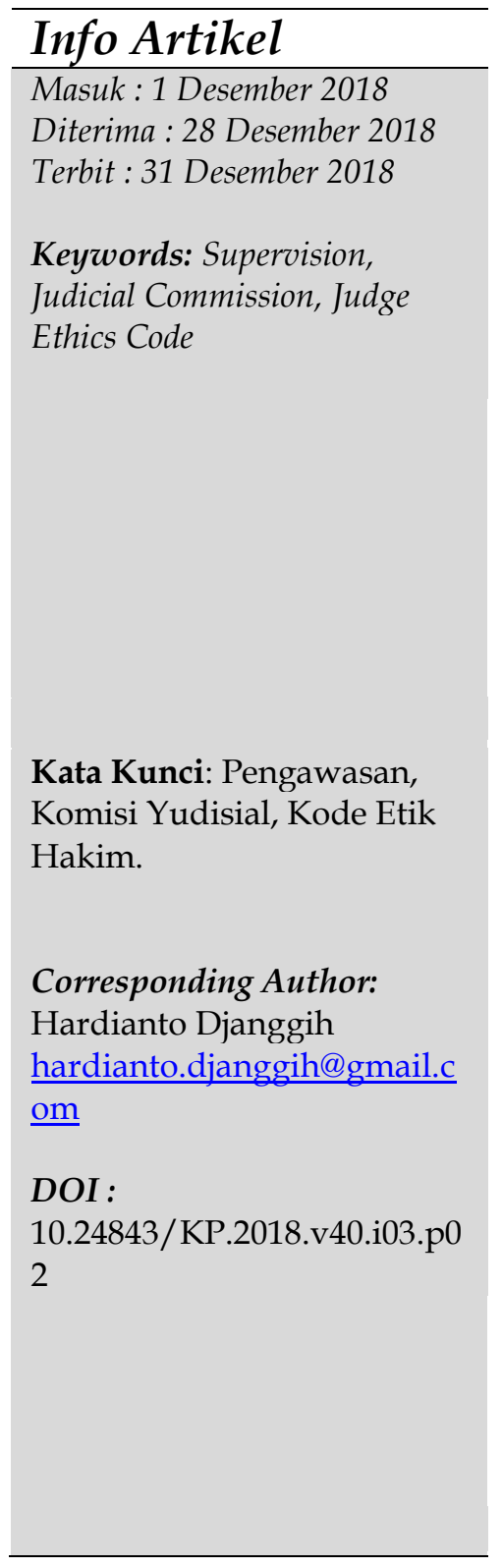

\begin{abstract}
This study aims to analyze the oversight process carried out by the Judicial Commission in Supervising the Judges Professional Code of Ethics. The type of research used is combining normative legal research and empirical law research (Juridical-Sociological). It is a research that uses a qualitative approach. The research results show that the supervision carried out by the Judicial Commission has not been effective and needs to be maximized properly. This is very reasonable, because the existence of the Judicial Commission in the constitutional system is very important to encourage judges to improve themselves and avoid behavior that is not commendable.
\end{abstract}

\begin{tabular}{l}
\hline Abstrak \\
\hline Penelitian ini bertujuan untuk menganalisis Proses \\
pengawasan yang dilakukan Komisi Yudisial dalam \\
Pengawasan Kode Etika Profesi hakim. Jenis penelitian \\
yang digunakan adalah menggabungkan penelitian hukum \\
normatif dan penelitian hukum empiris (Yuridis- \\
Sosiologis). Tipe Penelitian ini menggunakan pendekatan \\
kualitatif. Hasil penelitian menunjukkan bahwa \\
Pengawasan yang dilakukan oleh Komisi Yudisial belum \\
berjalan secara efektif dan perlu dimaksimalkan dengan \\
baik. Hal ini sangat beralasan, karena keberadaan Komisi \\
Yudisial dalam sistem ketatanegaraan sangat penting \\
untuk mendorong agar para hakim dapat memperbaiki diri \\
dan menghindari dari perilaku yang tidak terpuji.
\end{tabular}




\section{Pendahuluan}

Dewasa ini, perkembangan kekuasaan kehakiman di Indonesia, merupakan tantangan bagi hakim untuk menempatkan peranan hakim sebagai salah satu aparat penegak hukum dengan tugasnya sebagai salah satu penentu suatu keputusan perkara dari pihak-pihak yang bersengketa. Oleh karena itu, hakim dalam proses pengambilan keputusan hakim harus mandiri dan bebas dari pihak manapun. Hakim dalam mengambil keputusan hanya terikat pada peristiwa atau fakta-fakta yang relevan dan kaidah-kaidah hukum yang menjadi atau dijadikan syarat yuridis. ${ }^{1}$

Hakim merupakan konkritisasi hukum dan keadilan yang bersifat abstrak, dan digambarkan bahwa hakim sebagai wakil Tuhan di bumi untuk menegakkan hukum dan keadilan. ${ }^{2}$ Hakim melalui putusannya, dapat mengalihkan hak kepemilikan seseorang, mencabut kebebasan warga negara, menyatakan tidak sah tindakan sewenang-wenang pemerintah terhadap masyarakat, sampai dengan memerintahkan penghilangan hak hidup seseorang. ${ }^{3}$ Oleh sebab itu, semua kewenangan yang dimiliki oleh hakim harus dilaksanakan dalam rangka menegakkan hukum, kebenaran dan keadilan tanpa pandang bulu dengan tidak membeda-bedakan orang seperti diatur dalam lafal sumpah seorang hakim, di mana setiap orang sama kedudukannya di depan hukum dan hakim. Kewenangan hakim yang sangat besar itu menuntut tanggungjawab yang tinggi, sehingga putusan pengadilan yang diucapkan dengan irah-irah "Demi Keadilan berdasarkan Ketuhanan Yang Maha Esa" mengandung arti bahwa kewajiban menegakkan hukum, kebenaran dan keadilan itu wajib dipertanggung-jawabkan secara horizontal kepada semua manusia, dan secara vertikal dipertanggung-jawabkan kepada Tuhan Yang Maha Esa. ${ }^{4}$

Masyarakat saat ini disajikan banyak tontonan tentang kualitas peradilan dan perilaku hakim. Kritik dan sinisme peradilan telah mengarah kepada kertidakpercayaan masyarakat dan membentuk sikap skeptic. Setiap saat, hari, jam bahkan menit dan detik, media seolah-olah menelanjangi peradilan dengan mempertontonkan hakim yang dilaporkan dan ditangkap. Kondisi hakim dan peradilan kita tidak dalam kondisi memuaskan. Ruang pengadilan ternyata tidak steril bahkan terbuka bagi kegiatan konspirasi, ketidakjujuran, korupsi dan perilaku menyimpang yang terkait dengan kebohongan dan kenakalan. Satjipto Rahardjo menyatakan, "pengadilan seolah berubah menjadi pasar yang memperdagangkan putusan, pengadilan terlalu sering mencoreng martabatnya sendiri, dan bersama-sama dengan koruptor telah menjadi benalu di Negeri ini (judicial corruption). Dalam tulisan lain Satjipto mengatakan,

1 Wantu, F. M. (2013). Kendala Hakim dalam Menciptakan Kepastian Hukum, Keadilan, dan Kemanfaatan di Peradilan Perdata. Mimbar Hukum-Fakultas Hukum Universitas Gadjah Mada, 25(2), h.206.

2 Djanggih, H., \& Hipan, N. (2018). Pertimbangan Hakim dalam Perkarapencemaran Nama Baik Melalui Media Sosial (Kajian Putusan Nomor: 324/Pid./2014/PN. SGM). Jurnal Penelitian Hukum De Jure, 18(1), h.96.

3 Indrayati, R. (2016). Revitalisasai Peran Hakim Sebagai Pelaku Kekuasaan Kehakiman Dalam Sistem Ketatanegaraan Indonesia, Kertha Patrika, 38(1), h.118.

4 Afandi, V. K., Suantra, N., \& Nurmawati, M. (2015). Pengawasan Komisi Yudisial Terhadap Kehormatan Keluhuran Dan Martabat Perilaku Hakim Berdasarkan Uud Negara Republik Indonesia 1945. Jurnal Kertha Semaya, 1(1), h.2. 
"Indonesia tengah dilanda krisis besar. Mahkamah Agung dan pengadilan-pengadilan dibawahnya mendapat sorotan yang sangat keras dari masyarakat dan tidak puas oleh putusan-putusan yang dibuat serta perilaku para pejabat pengadilan." 5

Sebagai lembaga yang memiliki sifat independensi Komisi Yudisial tidak cukup untuk dikatakan sebagai lembaga yang dapat mewujudkan keinginan masyarakat untuk mengawasi sistem peradilan melalui hakim-hakim yang ada. Namun hal itu dapat terwujud ketika independensi tersebut diikuti dengan akuntabilitas dan tekad yang kuat dengan demikian dapat memperkuat kewenangan dan tugas Komisi Yudisial dalam menjalankan perannya. ${ }^{6}$ Di Indonesia kehadiran Komisi Yudisial dalam rumpun kekuasaan kehakiman, sebenarnya justru dilatarbelakangi sebagai gejala reaksional. Dikatakan sebagai gejala reaksional karena pertama; terdapat reaksi kekecewaan yang cukup akumulatif terhadap independensi peradilan di Indonesia. Sebastian Pompe misalnya, secara terang-terangan membuka sejarah kelam independensi peradilan di Indonesia dalam disertasinya yang berjudul The Indonesian Superme Court; A Study of Institutional Collapse. ${ }^{7}$

Sejak awal berdiri, Komisi Yudisial telah menetapkan garis Kebijakan yang menempatkan civil society sebagai mitra strategis. Dalam kerangka ini Komisi Yudisial menyadari betul bahwa upaya mensosialisasikan Kode Etik dan Pedoman Perilaku Hakim (KEPPH) kepada kalangan hakim tak akan bisa dilakukan tanpa memperkuat sistem di internal. Dalam kaitan itu, Komisi Yudisial melakukan penataan mekanisme pengaduan. Verifikasi atas pengaduan masyarakat merupakan langkah yang selalu ditempuh Komisi Yudisial. ${ }^{8}$ Perjalanan waktu telah membawa Komisi Yudisial semakin mantap menghadapi berbagai kendala dalam melaksanakan tugas dan mewujudkan kewenangan yang dimiliki sesuai amanat undang-undang. Masyarakat menaruh harapan sangat tinggi kepada Komisi Yudisial untuk memaksimalkan perannya dalam mengawasi hakim, agar suasana peradilan dapat terjamin dan mengutamakan keadilan. ${ }^{9}$

Kewenangan pengawasan hakim yang dimiliki Komisi Yudisial bertujuan untuk memperkuat akuntabilitas dunia peradilan. Kewenangan tersebut tercantum dalam Undang-Undang Nomor 48 Tahun 2009, tentang Kekuasaan Kehakiman dan khususnya Undang-Undang Nomor 18 Tahun 2011, pasal 20A ayat (1) poin d yang berbunyi: Dalam melaksanakan tugas, Komisi Yudisial wajib menjaga kemandirian dan kebebasan hakim dalam memeriksa, mengadili, dan memutus perkara. ${ }^{10}$

\footnotetext{
${ }^{5}$ Ridwan, R., \& TAHIR, H. (2016). Persepsi Hakim Terhadap Pengawasan Komisi Yudisial Bagi Perilaku Hakim (Studi Di Pengadilan Negeri Makassar). Jurnal Tomalebbi, 2(2), h.50.

6 Debie Zilviany Hormati (2017), Ibid.

7 Rishan, I., \& Putra, A. (2017). Model dan Kewenangan Komisi Yudisial: Komparasi dengan Bulgaria, Argentina, Afrika Selatan, dan Mongolia. Jurnal Hukum IUS QUIA IUSTUM, 24(3), h.353.

8 Fedrian, D. Membumikan Kode Etik \& Pedoman Perilaku Hakim, Buletin Komisi Yudisial, 7(2), h. 13.

9 Hormati, D. S. (2017). Kajian Yuridis Tentang Peran Komisi Yudisial Dalam Penegakkan Kode Etik Mengenai Perilaku Hakim. Lex Privatum, 5(8), h.89.

10 Komisi Yudisial. (2012). Tegaskan Menjaga Independensi Peradilan, Buletin Komisi Yudisial, $8(2)$, h.9.
} 
Terhadap kewenangan yang diberikan kepada Komisi Yudisial dalam hal pengawasan perilaku hakim jika dikaitkan dengan teori kewenangan yang dikemukan Ateng Syarifudin bahwa kewenangan merupakan kekuasaan formal, kekuasaan yang berasal dari kekuasaan yang diberikan oleh undang-undang. ${ }^{11}$

\section{Metode Penelitian}

Jenis penelitian yang digunakan adalah menggabungkan metode penelitian hukum normatif dan penelitian hukum empiris (Yuridis-Sosiologis). Tipe penelitian adalah dengan dua pendekatan, yakni dengan pendekatan kualitatif dan pendekatan kuantitatif. Hasil penelitian diuraikan secara deskriptif terhadap berbagai sumber data yang ditemukan dalam penelitian ini dengan menguraikan secara filosofis, teoritis dan dogmatis terkait pengawasan Komisi Yudisial dalam mewujudkan hakim yang bermartabat.

\section{Hasil dan Pembahasan}

\subsection{Proses Pengawasan Yang Dilakukan Komisi Yudisial}

Undang-Undang mengamanatkan bahwa Komisi Yudisial merupakan pengawas eksternal perilaku hakim berpedoman pada Kode Etik dan Pedoman Perilaku Hakim yang disusun bersama oleh Komisi Yudisial dan Mahkamah Agung. Faktanya bahwa sebagian besar laporan masyarakat yang disampaikan kepada Komisi Yudisial menyangkut perilaku hakim dalam mengadili dan/atau memutus/menetapkan putusan, sehingga tidak bisa terhindarkan dalam memeriksa laporan masyarakat, Komisi Yudisial harus membaca putusan sebagai pintu masuk dan/atau bukti terjadi atau tidaknya pelanggaran kode etik dan pedoman perilaku hakim. ${ }^{12}$

Reformasi melahirkan Komisi Yudisial sebagai lembaga yang berwenang untuk menjaga dan menegakkan kehormatan, keluhuran martabat, serta perilaku hakim. Sesuai Pasal 20 ayat (1) Undang-Undang Nomor 18 Tahun 2011 tentang Perubahan atas Undang-Undang Nomor 22 Tahun 2004 tentang Komisi Yudisial, salah satu tugas yang melekat pada lembaga ini adalah pengawasan hakim.

Berdasarkan hal tersebut, Komisi Yudisial memiliki tugas:

a. Melakukan pemantauan dan pengawasan terhadap perilaku hakim;

b. Menerima laporan dari masyarakat berkaitan dengan pelanggaran Kode Etik dan/atau Pedoman Perilaku Hakim;

c. Melakukan verifikasi, klarifikasi, dan investigasi terhadap laporan dugaan pelanggaran Kode Etik dan/ atau Pedoman Perilaku Hakim secara tertutup;

d. Memutuskan benar tidaknya laporan dugaan pelanggaran Kode Etik dan/atau Pedoman Perilaku Hakim; dan

e. Mengambil langkah hukum dan/atau langkah lain terhadap orang perseorangan,

11 Syarifudin, A. (1992), Kewenangan Pengurusan Perizinan, Pusat Pendidikan dan Pelatihan St. Aloysius, Bandung.

12 Rishan, I. (2013). Komisi Yudisial: suatu upaya mewujudkan wibawa peradilan. Genta Press. H.4. 
kelompok orang, atau badan hukum yang merendahkan kehormatan dan keluhuran martabat Hakim.

Sebagai pengawas eksternal, Komisi Yudisial bersama pengawas internal kehakiman, Badan Pengawasan Mahkamah Agung, menyelaraskan pelaksanaan fungsi pengawasan tersebut melalui beberapa peraturan bersama. Salah satunya, keputusan bersama Mahkamah Agung Republik Indonesia dan Komisi Yudisial Republik Indonesia Nomor: 047/KMA/SKB/IV/2009-02/SKB/P.KY/IV/2009 tentang Kode Etik dan Pedoman Perilaku Hakim (KEPPH). Selain itu, terdapat pula beberapa peraturan bersama, seperti: Peraturan Bersama tentang Panduan Penegakan Kode Etik dan Pedoman Perilaku Hakim; Peraturan Bersama tentang Tata Cara Pemeriksaan Bersama; dan Peraturan Bersama tentang Tata Cara Pembentukan, Tata Kerja, dan Tata Cara Pengambilan Keputusan Majelis Kehormatan Hakim yang disusun tahun 2012.

Dalam hal proses adanya dugaan terhadap hakim melakukan pelanggaran kode etik, berikut diuraikan tata cara laporan yang diajukan masyarakat.

1. Laporan ditulis dalam bahasa Indonesia ditujukan kepada Ketua Komisi Yudisial.

2. Mencantumkan identitas Pelapor, meliputi: nama, alamat dan nomor telepon yang bisa dihubungi.

3. Mencantumkan identitas penerima kuasa (apabila menggunakan kuasa), meliputi: nama, alamat, pekerjaan dan nomor telepon yang bisa dihubungi.

4. Mencantumkan identitas terlapor, meliputi: nama, jabatan, instansi dan / atau nomor perkara jika terkait dengan putusan.

5. Memuat pokok laporan, berisi hal penting / pokok pikiran yang akan dipelajari, diteliti/ditelaah oleh Komisi Yudisial.

6. Kronologis / Kasus Posisi, ditulis secara jelas dan singkat tentang persoalan yang terjadi.

7. Hal yang dimohonkan untuk dilakukan oleh Komisi Yudisial.

8. Lampiran laporan (kelengkapan data):

a. Bukti Formal

- Fotokopi identitas Pelapor yang masih berlaku (KTP/SIM/Paspor)

- Khusus Advokat melampirkan Fotokopi KTA (Kartu Tanda Advokat) yang masih berlaku

- Surat kuasa khusus untuk menyampaikan laporan ke Komisi Yudisial (khusus yang menggunakan kuasa)

b. Bukti pendukung materiil data dan/atau fakta yang menguatkan laporan mengenai dugaan Pelanggaran Kode Etik dan Pedoman Perilaku Hakim, antara lain:

- Fotokopi Salinan resmi putusan / penetapan yang dilaporkan (mengikuti tingkat peradilan, seperti tingkat pertama, banding, kasasi dan PK)

- Video, audio visual, rekaman persidangan (apabila ada) Foto, kliping Koran (apabila ada)

- keterangan saksi secara tertulis di atas kertas bermaterai, minimal 2 (dua) orang saksi (apabila ada). 
9. Terkait dengan laporan mengenai eksekusi harus memuat dan melampirkan:

- Alasan penundaan, penghentian atau pembatalan eksekusi

- Fotokopi salinan resmi putusan terkait dengan eksekusi

- Fotokopi surat permohonan eksekusi (bagi pelapornya pemohon eksekusi)

- Fotokopi surat penetapan eksekusi

- Fotokopi surat teguran (aanmaning)

- Fotokopi berita acara pelaksanaan eksekusi

- Fotokopi berita acara sita eksekusi.

10. Laporan ditandatangani oleh Pelapor atau kuasanya.

Komisi Yudisial dalam melakukan pemeriksaan laporan masyarakat, berpedoman pada 10 butir perilaku utama sebagaimana dimaksud dalam Kode Etik dan Perilaku Hakim. Komisi Yudisial Republik Indonesia adalah Lembaga Negara yang diorientasikan untuk membangun sistem checks and balances dalam sistem kekuasaan kehakiman. Melihat kewenangan yang dimiliki, Komisi Yudisial merupakan organisasi publik yang dituntut bisa menjalankan aktivitasnya secara fleksibel dan mudah dikembangkan sejalan dengan perkembangan situasi eksternal.

Adapun beberapa perbuatan yang dilarang dan tidak boleh dilakukan oleh hakim, diantaranya: ${ }^{13}$

1. Hakim dilarang memberikan kesan bahwa salah satu pihak yang tengah berperkara atau kuasanya termasuk penuntut dan saksi berada dalam posisi yang istimewa untuk mempengaruhi hakim yang bersangkutan.

2. Hakim tidak boleh meminta/menerima dan harus mencegah suami atau istri hakim, orang tua, anak atau anggota keluarga hakim lainnya, untuk meminta atau menerima janji, hadiah, hibah, warisan, pemberian, penghargaan dan pinjaman atau fasilitas dari: advokat; penuntut; orang yang sedang diadili; pihak lain yang kemungkinan kuat akan diadili.

3. Hakim dilarang menggunakan wibawa pengadilan untuk kepentingan pribadi, keluarga atau pihak ketiga lainnya.

4. Hakim dilarang melakukan tawar-menawar putusan, memperlambat pemeriksaan perkara, menunda eksekusi atau menunjuk advokat tertentu dalam menangani suatu perkara di pengadilan, kecuali ditentukan lain oleh undang-undang.

5. Hakim dilarang menggunakan wibawa jabatan sebagai hakim untuk mengejar kepentingan pribadi, anggota keluarga atau siapapun juga dalam hubungan finansial.

${ }^{13}$ Lihat Pasal 5 s.d pasal 11 Peraturan Bersama Ketua Mahkamah Agung Republik Indonesia dan Ketua Komisi Yudisial Republik Indonesia Nomor: 02/PB/MA/IX/201202/PB/P.KY/09/2012 Tentang Panduan Penegakan Kode Etik Dan Pedoman Perilaku Hakim 
Apabila hakim melakukan perbuatan yang dilarang tersebut, maka hakim dapat dikatakan melakukan pelanggaran. Pelanggaran adalah setiap sikap, ucapan, dan/atau perbuatan yang dilakukan oleh seorang hakim yang bertentangan dengan normanorma yang ditentukan dalam kode etik dan pedoman perilaku hakim. ${ }^{14}$ Seorang hakim yang terbukti melakukan pelanggaran terhadap kode etik akan dikenakan sanksi.

Sejak berdiri tahun 2005, Komisi Yudisial terus memperoleh kepercayaan masyarakat sebagai lembaga pengawasan hakim. Hingga Desember 2017, Komisi Yudisial telah menerima 16.274 (enam belas ribu dua ratus tujuh puluh empat) laporan masyarakat dan 14.066 (empat belas ribu enam puluh enam) surat tembusan.

Tabel 1

Rekapitulasi Laporan Masyarakat dan Tembusan Tahun 2005 - Desember 2017

\begin{tabular}{|c|c|c|c|}
\hline No & Tahun & $\begin{array}{c}\text { Jumlah } \\
\text { Laporan }\end{array}$ & $\begin{array}{c}\text { Surat } \\
\text { Tembusan }\end{array}$ \\
\hline 1 & 2005 & 388 & 0 \\
\hline 2 & 2006 & 485 & 0 \\
\hline 3 & 2007 & 497 & 0 \\
\hline 4 & 2008 & 649 & 0 \\
\hline 5 & 2009 & 860 & 0 \\
\hline 6 & 2010 & 1452 & 1642 \\
\hline 7 & 2011 & 1717 & 1622 \\
\hline 8 & 2012 & 1470 & 1779 \\
\hline 9 & 2013 & 2244 & 1928 \\
\hline 10 & 2014 & 1964 & 2003 \\
\hline 11 & 2015 & 1491 & 1751 \\
\hline 12 & 2016 & 1682 & 1899 \\
\hline 13 & 2017 & 1473 & 1546 \\
\hline
\end{tabular}

Sumber: Komisi Yudisial tahun 2017

Komisi Yudisial berupaya meningkatkan perbaikan sistem penanganan laporan sesuai prinsip transparansi dan akuntabilitas. Salah satunya melalui Peraturan Komisi Yudisial RI Nomor 2 Tahun 2015 tentang Penanganan Laporan Masyarakat.

Laporan yang masuk akan diverifikasi kelengkapan persyaratan untuk dapat diregister. Hanya laporan yang memenuhi syarat administrasi dan substansi, maka dapat dilakukan registrasi. Setelah diregistrasi, Komisi Yudisial akan melakukan proses penanganan lanjutan dengan melakukan penanganan analisis laporan berupa anotasi untuk menelaah dan mengidentifikasi terkait dugaan pelanggaran KEPPH.

14 Lihat Pasal 1 s.d pasal 6 Peraturan Bersama Ketua Mahkamah Agung Republik Indonesia dan Ketua Komisi Yudisial Republik Indonesia Nomor: 02/PB/MA/IX/201202/PB/P.KY/09/2012 Tentang Panduan Penegakan Kode Etik Dan Pedoman Perilaku Hakim 
Tabel 2

Hasil Verifikasi Laporan Masyarakat Dan Yang Diregistrasi 2005 - Desember 2017

\begin{tabular}{|c|c|c|}
\hline No & Tahun & Laporan Yang Diregistrasi \\
\hline 1 & 2005 & 382 \\
\hline 2 & 2006 & 481 \\
\hline 3 & 2007 & 228 \\
\hline 4 & 2008 & 330 \\
\hline 5 & 2009 & 380 \\
\hline 6 & 2010 & 757 \\
\hline 7 & 2011 & 847 \\
\hline 8 & 2012 & 577 \\
\hline 9 & 2013 & 709 \\
\hline 10 & 2014 & 545 \\
\hline 11 & 2015 & 361 \\
\hline 12 & 2016 & 416 \\
\hline 13 & 2017 & 411 \\
\hline$S u m b$ & & \\
\hline
\end{tabular}

Sumber: Komisi Yudisial tahun 2017

Jika ada laporan yang terindikasi pelanggaran $\mathrm{KEPPH}$, maka akan dilakukan pemeriksaan terhadap pelapor, saksi, dan/atau ahli. Tujuannya, untuk memperoleh bukti-bukti yang menguatkan laporan tersebut dapat ditindaklanjuti atau tidak dapat ditindaklanjuti oleh Komisi Yudisial. Hasil analisis dan/atau pemeriksaan pelapor dan saksi dituangkan dalam bentuk Laporan Penanganan Pendahuluan (LPP) yang akan dibawa ke Sidang Panel. Proses ini dilakukan secara tertutup dan bersifat rahasia. Sidang Panel merupakan forum pengambilan keputusan oleh tiga Anggota Komisi Yudisial untuk memutuskan apakah laporan masyarakat itu dapat ditindaklanjuti atau tidak dapat ditindaklanjuti. Proses ini pun dilakukan secara tertutup dan bersifat rahasia.

Laporan yang putusannya dapat ditindaklanjuti karena terdapat dugaan pelanggaran $\mathrm{KEPPH}$, maka akan dilakukan pemeriksaan atau permintaan klarifikasi kepada hakim terlapor. Hasil pemeriksaan atau klarifikasi hakim terlapor dituangkan dalam bentuk Laporan Hasil Pemeriksaan (LHP). Sebaliknya, apabila Sidang Panel memutuskan laporan tersebut tidak dapat ditindaklanjuti karena tidak terdapat dugaan pelanggaran $\mathrm{KEPPH}$, maka penanganan laporan masyarakat dianggap berakhir. 
Tabel 3

Pemeriksaan Hakim, Pelapor dan Saksi Tahun 2005 - Desember 2017

\begin{tabular}{|c|c|c|c|}
\hline \multirow{2}{*}{ Tahun } & \multicolumn{2}{|c|}{ Terperiksa } & \multirow{2}{*}{ Jumlah } \\
\cline { 2 - 3 } & Hakim & Pelapor dan saksi & \\
\hline 2005 & 30 & 6 & 36 \\
\hline 2006 & 56 & 27 & 83 \\
\hline 2007 & 10 & 64 & 74 \\
\hline 2008 & 36 & 71 & 107 \\
\hline 2009 & 96 & 137 & 233 \\
\hline 2010 & 153 & 147 & 300 \\
\hline 2011 & 77 & 206 & 283 \\
\hline 2012 & 160 & 322 & 482 \\
\hline 2013 & 252 & 432 & 684 \\
\hline 2014 & 148 & 522 & 670 \\
\hline 2015 & 115 & 407 & 522 \\
\hline 2016 & 93 & 477 & 570 \\
\hline 2017 & 50 & 427 & 477 \\
\hline Sunn & & & \\
\hline
\end{tabular}

Sumber: Komisi Yudisial tahun 2017

Sementara untuk memutus laporan masyarakat terbukti melanggar KEPPH atau tidak, maka dilakukan melalui Sidang Pleno. Sidang ini merupakan forum pengambilan keputusan Komisi Yudisial untuk memutus laporan masyarakat terbukti melanggar KEPPH atau tidak terbukti. Sidang Pleno dilakukan oleh tujuh orang atau paling sedikit lima orang Anggota Komisi Yudisial. Sidang Pleno dilakukan secara tertutup dan bersifat rahasia. Hasil Sidang Pleno tersebut tertuang dalam Putusan Sidang Pleno. Apabila di dalam Sidang Pleno hakim terlapor terbukti melakukan pelanggaran $\mathrm{KEPPH}$, Komisi Yudisial mengusulkan penjatuhan sanksi terhadap hakim yang diduga melakukan pelanggaran kepada Mahkamah Agung, sebagaimana diatur dalam UU Nomor 18 Tahun 2011 tentang Perubahan atas UU Nomor 22 Tahun 2004 tentang Komisi Yudisial.

Sementara apabila di dalam Sidang Pleno hakim terlapor tidak terbukti melakukan pelanggaran KEPPH, maka Komisi Yudisial membuat surat pemberitahuan tidak terbukti kepada pelapor dan memulihkan nama baik hakim terlapor. Pemulihan nama baik ini dilakukan melalui surat pemberitahuan hasil akhir penanganan laporan yang disampaikan kepada hakim terlapor dengan tembusan kepada atasan hakim terlapor secara berjenjang.

\subsection{Mekanisme Penjatuhan Sanksi Hakim oleh Komisi Yudisial}

Pasal 22D ayat (1) Undang-Undang Nomor 18 Tahun 2011 menyatakan, Komisi Yudisial menyampaikan usul penjatuhan sanksi kepada Mahkamah Agung terhadap hakim terlapor yang melanggar KEPPH. Sanksi tersebut berupa sanksi ringan, sanksi sedang dan sanksi berat. 
1. Sanksi ringan terdiri dari: ${ }^{15}$

a. Teguran lisan;

b. Teguran tertulis;

c. Pernyataan tidak puas secara tertulis.

2. Sanksi sedang terdiri dari:

a. Penundaan kenaikan gaji berkala paling lama 1 (satu) tahun;

b. Penurunan gaji sebesar 1 (satu) kali kenaikan gaji berkala paling lama 1 (satu) tahun;

c. Penundaan kenaikan pangkat paling lama 1 (satu) tahun;

d. Hakim nonpalu paling lama 6 (enam) bulan;

e. Mutasi ke pengadilan lain dengan kelas yang lebih rendah;

f. Pembatalan atau penangguhan promosi.

3. Sedangkan sanksi berat terdiri dari:

a. Pembebasan dari jabatan;

b. Hakim nonpalu lebih dari 6 (enam) bulan dan paling lama 2 (dua) tahun; penurunan pangkat pada pangkat yang setingkat lebih rendah untuk paling lama 3 (tiga) tahun;

c. Pemberhentian tetap dengan hak pensiun;

d. Pemberhentian tidak dengan hormat

Adapun yang dimaksud hakim nonpalu adalah hakim yang dijatuhi sanksi tidak diperkenankan memeriksa dan mengadili perkara dalam tenggang waktu tertentu. ${ }^{16}$ Pemberhentian adalah pemberhentian dengan hormat atau pemberhentian tidak dengan hormat sedangkan Pemberhentian sementara adalah pemberhentian untuk waktu tertentu terhadap seorang hakim sebelum adanya putusan pengadilan dalam perkara pidana yang dijalaninya berkekuatan hukum tetap atau keputusan pemberhentian tetap sesuai dengan peraturan perundang-undangan, sementara yang dimaksud dengan pemberhentian tetap dengan hak pensiun sebagaimana dimaksud dengan Undang-Undang Nomor 18 Tahun 2011 tentang Perubahan Atas Undang-Undang Nomor 22 Tahun 2004 tentang Komisi Yudisial, dimaknai sebagai pemberhentian dengan hormat. ${ }^{17}$

Dalam sisi pengawasan, sanksi yang diberikan Komisi Yudisial memang hanya sebatas rekomendasi. Komisi Yudisial tidak diberikan wewenang untuk memberikan sanksi yang bersifat final dan mengikat, sehingga Mahkamah Agung yang dapat menindaklanjuti rekomendasi tersebut. Mahkamah Agung menjatuhkan sanksi terhadap hakim terlapor yang melakukan pelanggaran KEPPH yang diusulkan oleh Komisi Yudisial dalam waktu paling lama 60 (enam puluh) hari terhitung sejak tanggal usulan diterima.

15 Lihat Pasal 19 Peraturan Bersama Ketua Mahkamah Agung Republik Indonesia dan Ketua Komisi Yudisial Republik Indonesia Nomor: 02/PB/MA/IX/2012 -02/PB/P.KY/09/2012 Tentang Panduan Penegakan Kode Etik Dan Pedoman Perilaku Hakim.

16 Lihat Pasal 1 angka 15 Peraturan Bersama Ketua Mahkamah Agung Republik Indonesia dan Ketua Komisi Yudisial Republik Indonesia Nomor: 02/PB/MA/IX/2012 02/PB/P.KY/09/2012 Tentang Panduan Penegakan Kode Etik Dan Pedoman Perilaku Hakim

17 Lihat Pasal 1 angka 16, 17 dan 18 Peraturan Bersama Ketua Mahkamah Agung Republik Indonesia dan Ketua Komisi Yudisial Republik Indonesia Nomor: 02/PB/MA/IX/2012 02/PB/P.KY/09/2012 Tentang Panduan Penegakan Kode Etik Dan Pedoman Perilaku Hakim 
Usulan penjatuhan sanksi tersebut berlaku secara otomatis dan wajib dilaksanakan oleh Mahkamah Agung, dengan syarat, pertama jika tidak terjadi perbedaan pendapat antara Komisi Yudisial dan Mahkamah Agung mengenai usulan Komisi Yudisial tentang penjatuhan sanksi, dan kedua, Mahkamah Agung belum menjatuhkan sanksi dalam jangka waktu 60 (enam puluh) hari, sesuai dengan Pasal 22D ayat (3) UU Komisi Yudisial.

Apabila terjadi perbedaan pendapat antara Komisi Yudisial dan Mahkamah Agung mengenai usulan sanksi Komisi Yudisial berupa sanksi ringan, sedang, dan berat, selain usul pemberhentian tetap dengan hak pensiun dan pemberhentian tetap tidak dengan hormat, maka dilakukan pemeriksaan bersama antara Komisi Yudisial dan Mahkamah Agung terhadap hakim yang bersangkutan.

Bentuk pengawasan Komisi Yudisial yang hanya bersifat perventif tidak boleh diindektikkan dengan pengawasan yang bersifat refresif karena pengawasan refresif ini hanya merupakan wewenang lembaga penegak hukum (polisi, jaksa, hakim) bukan wewenang Komisi Yudisial selaku lembaga pengawasan. Sebagai institusi yang lahir dari hasil perubahan UUD 1945, keberadaan Lembaga Komisi Yudisial juga dilatarbelakangi oleh adanya kehendak kuat agar kekuasaan kehakiman yang dilakukan Mahkamah Agung dan Mahkamah Konstitusi benar-benar merupakan kekuasaan yang merdeka untuk menyelenggarakan peradilan guna menegakkan hukum dan peradilan.

Pengawasan yang dilakukan oleh Komisi Yudisial terhadap perilaku hakim merupakan bentuk pengawasan etika hakim sebagai pengemban profesi yang sangat berkaitan dengan teori etika yang diungkapkan $\mathrm{O}^{\prime}$ Leary, $\mathrm{C}$ and Cotter bahwa etika merupakan tatanan moral yang ditelah disepakati bersama dalam suatu profesi dan ditujukan untuk anggota profesi tersebut dengan motivasi dasar dalam melakukan tindakan etis bukanlah keinginan dan kesadaran individu tersebut tetapi karena adanya peraturan hukum. ${ }^{18}$

Merujuk teori pengawasan yang dikemukakan Muchan, bahwa pengawasan adalah kegiatan untuk menilai suatu pelaksanaan tugas secara defacto, sedangkan tujuan pengawasan hanya terbatas pada kecocokan apakah kegiatan yang dilaksanakan telah sesuai dengan tolak ukur yang telah ditetapkan sebelumnya. ${ }^{19}$ Begitu halnya yang dikatakan Bagir Manan, yang memandang pegawasan sebagai kontrol sebagai sebuah fungsi sekaligus hak, sehingga lazim disebut dengan fungsi kontrol atau hak kontrol, kontrol mengandung dimensi pengawasan dan pengendalian, pengawasan bertalian dengan arahan (directife). ${ }^{20}$ Dengan demikian, dari kedua pendapat tersebut, menurut penulis bahwa pengawasan hakim dilakukan untuk mencegah adanya perilaku hakim dalam menjatuhkan putusan yang dapat berpeluang sangat besar untuk salah dan

18 Lihat teori Etika O'Leary, C and Cotter, D, 2000, h. 115.

19 Muchsan, S. P. T. P. A. (1992). Pemerintah dan Peradilan Tata Usaha Negara di Indonesia. Liberty, Yogyakarta, h.37.

20 Manan, B. (2001). Menyongsong fajar otonomi daerah. Pusat Studi Hukum, Fakultas Hukum, Universitas Islam Indonesia, h.20. 
tidak adil serta gegabah, banyak bukti yang otentik bahwa putusan Hakim adalah didasari atas ketidakadilan yang dilakukan. Untuk mengembalikan kewibawaan hakim di seluruh Indonesia, diperlukan Lembaga Komisi Yudisial yang dapat menghukum Hakim atas putusannya. Hakim yang benar adil dan jujur untuk menegakkan kewibawaan hukum akan tidak takut terhadap putusannya. Salah satu adalah melakukan pengawasan terhadap hakim dan memberikan penilaian atas putusan Hakim. Dari putusan tersebut dapat diketahui apakah ada dugaan pelanggaran kode etik yang dilakukan Hakim.

Pengawasan Komisi Yudisial telah diatur secara konstitusional dan jelas tugasnya menjaga harkat dan martabat perilaku hakim. Bentuk pengawasan refresif (penindakan) dan perventif (pencegahan) termasuk dalam kewenangan Komisi Yudisial untuk memaksimalkan pengawasannya dan Komisi Yudisial hanya bersifat eksternal artinya hanya perilaku hakim yang diawasi dan bukan pada teknis yudisial yang merupakan kewenangan Mahkamah Agung. Keberadaan Komisi Yudisial sangat berpengaruh pada kualitas kinerja Hakim karena tentunya hakim lebih profesional dan berhati-hati dalam menjalankan tugasnya, namun Komisi Yudisial saat ini tampaknya sudah ada yang keluar dari ranah hak pengawasannya yaitu ingin mencampuri hal-hal yang menyangkut teknis yudisial seperti eksekusi putusan yang pada dasarnya merupakan kewenangan Mahkamah Agung.

Upaya pengawasan yang dilakukan Lembaga Komisi Yudisial untuk tetap menjaga martabat dan wibawa peradilan, maka masyarakat Indonesia diharapkan lebih mendukung kehadiran Lembaga Komisi Yudisial ini. Komisi Yudisial harus lebih meningkatkan cara pengawasannya dan mengintropeksi kelembagaannya agar tidak melenceng dari hak dasar pengawasannya dan sebaiknya hakim yang di jatuhi sanksi terus di promosikan di media agar lebih memberikan efek jera bagi hakim dikemudian hari.

\section{Kesimpulan}

Pengawasan yang dilakukan oleh Komisi Yudisial belum berjalan secara efektif dan perlu dimaksimalkan dengan baik. Hal ini sangat beralasan, karena keberadaan Komisi Yudisial dalam sistem ketatanegaraan sangat penting untuk mendorong agar para hakim dapat memperbaiki diri dan menghindari dari perilaku yang tidak terpuji. Hal lain pula disebabkan karena Komisi Yudisial tidak mempunyai kewenangan untuk menjatuhkan hukuman administrasi sendiri terhadap hakim dan tidak mempunyai kewenangan penyidikan terhadap para hakim yang terbukti di dalam pemeriksaan melanggar aturan pidana. Sehingga, jika pelaksanaan tugas Komisi Yudisial dalam menjaga dan menegakkan kehormatan, keluhuran martabat, dan perilaku hakim dapat dijalankan dengan baik, maka secara tidak langsung pasti akan berpengaruh terhadap upaya membangun sistem peradilan yang terpercaya (respectable judiciary). 


\section{Daftar Pustaka}

Buku

Syarifudin, A. (1992), Kewenangan Pengurusan Perizinan, Pusat Pendidikan dan Pelatihan St. Aloysius, Bandung.

SManan, B. (2001). Menyongsong Fajar Otonomi Daerah, Yogyakarta: Pusat Studi Fakultas Hukum UII.

Rishan, I. (2013). Komisi Yudisial Suatu Upaya Mewujudkan Wibawa Peradilan, Yogyakarta: Genta Press.

Muchsan, (1992). Sistem Pengawasan terhadap Perbuatan Aparat Pemerintah dan Peradilan Tata Usaha Negara, Yogyakarta: Liberty

Jurnal

Afandi, V.K. et.al.(2013). Pengawasan Komisi Yudisial Terhadap Kehormatan Keluhuran Dan Martabat Perilaku Hakim Berdasarkan Uud Negara Republik Indonesia 1945, Jurnal Kertha Semaya, 1(1).

Djanggih, H., \& Hipan, N. (2018). Pertimbangan Hakim dalam Perkarapencemaran Nama Baik Melalui Media Sosial (Kajian Putusan Nomor: 324/Pid./2014/PN. SGM). Jurnal Penelitian Hukum DE JURE, 18(1), 93102.DOI: http://dx.doi.org/10.30641/dejure.2018.V18.93-102

Fedrian, D.F. (2012). Membumikan Kode Etik \& Pedoman PerilakuHakim, Buletin Komisi Yudisial, 7(2).

Hormati, D. Z. (2017). Kajian Yuridis Tentang Peran Komisi Yudisial Dalam Penegakkan Kode Etik Mengenai Perilaku Hakim, Jurnal Lex Privatum, 5(8).

Indrayati, R. (2016). Revitalisasai Peran Hakim Sebagai Pelaku Kekuasaan Kehakiman Dalam Sistem Ketatanegaraan Indonesia, KerthaPatrika, 38(1).DOI:https://doi.org/10.24843/KP.2016.v38.i02.p02

Ridwan R.H. \& Tahir. H. (2014). Persepsi Hakim Terhadap Pengawasan Komisi Yudisial Bagi Perilaku Hakim (Studi Di Pengadilan Negeri Makassar), Jurnal Tomalebbi, 1(1).

Rishan, I. \&Pangaribuan, A.P.H. (2017). Model dan Kewenangan Komisi Yudisial: Komparasi dengan Bulgaria, Argentina, Afrika Selatan, dan Mongolia, Jurnal IusQuiaIustum, 23(3).DOI: https:/ / doi.org/10.20885/iustum.vol24.iss3.art1

Wantu, F.M. (2016). Kendala Hakim Dalam Menciptakan Kepastian Hukum, Keadilan, dan Kemanfaatan di Peradilan Perdata, Jurnal Mimbar Hukum, 25(2).DOI: https://doi.org/10.22146/jmh.16092

Yudisial, K. (2012). Tegaskan Menjaga Independensi Peradilan, Buletin Komisi Yudisial, $8(2)$. 


\section{Peraturan Perundang-Undangan}

Undang-Undang Dasar Republik Indonesia Tahun 1945

Undang-Undang Republik Indonesia Nomor 22 Tahun 2004 Tentang Komisi Yudisial (Lembaran Negara Republik Indonesia Tahun 2004 Nomor 89)

Undang-Undang Republik Indonesia Nomor 48 Tahun 2009 tetangKekuasan Pokok Kehakiman (Lembaran Negara Republik Indonesia Tahun 2009 Nomor 157, Tambahan Lembaran Negara Republik Indonesia Nomor 5076).

Undang-Undang Nomor 18 Tahun 2011 tentang Komisi Yudisial (Lembaran Negara Republik Indonesia Tahun 2011 Nomor 106, Tambahan Lembaran Negara Republik Indoneisa Nomor 5250).

Peraturan Bersama Ketua Mahkamah Agung Republik Indonesia dan Ketua Komisi Yudisial Republik Indonesia Nomor:02/PB/MA/IX/2012 02/PB/P.KY/09/2012 Tentang Panduan Penegakan Kode Etik Dan Pedoman Perilaku Hakim. 